\section{Uticaj metaboličkog sindroma na koronarograf- ske karakteristike osoba sa prebolelim infarktom miokarda}

Dušan M. Miljković

Dom zdravlja Varvarin, Srbija

\section{Sažetak}

Uvod. Prethodna epidemiološka i klinička ispitivanja potvrdila su povezanost između metaboličkog sindroma i povećanog rizika za nastanak koronarne bolesti. Pokazana je značajna povezanost ovog sindroma sa angiografski težim lezijama koronarnih arterija.

Cilj rada. Cilj rada je bio da ispitamo značaj i uticaj metaboličkog sindroma na težinu angiografskih promena koronarnih arterija kod bolesnika sa infarktom miokarda.

Metod. Ispitivanjem su obuhvaćena 143 bolesnika sa infarktom miokarda, $81(58,7 \pm 6,2)$ sa i $62(54,9 \pm 10,3)$ bez metaboličkog sindroma $(\mathrm{p}<0,01)$. Kod svih ispitanika urađeni su klinički pregledi, antropometrijska merenja, laboratorijska i koronarografska dijagnostika. Za postavljanje dijagnoze metaboličkog sindroma korišćeni su kriterijumi Američkog udruženja za srce i Nacionalnog instituta za srce, pluća i krv.

Rezultati. Osobe sa metabolićkim sindromom, u poređenju sa onima bez MS, imaju: jednosudovnu 8,6\% vs 46,8\% $(\mathrm{p}<0,001)$, dvosudovnu $25,9 \%$ vs $32,3 \%(\mathrm{p}>0,05)$, trosudovnu $65,4 \%$ vs $21,0 \%(\mathrm{p}<0,001)$, višesudovnu bolest $91,3 \%$ vs $53,2 \%(p<0,001)$. Od pojedinačnih koronarnih arterija, značajne stenoze nađene su kod ispitanika sa MS, u poređenju sa ispitanicima bez MS: LAD 88,9\% vs 71,0\% (p<0,01), LCX $64,2 \%$ vs 29,0\% (p<0,01), RCA 80,2\% vs 61,3\% ( $<<0,01)$, LM 14,8\% vs 1,6\%.

Zaključak. Pacijenti sa MS imaju teže angiografske promene na koronarnim arterijama sa većom učestalošću trosudovne i višesudovne bolesti i stenoza LAD, LCX, RCA, LM, u poređenju sa onima bez MS, što pokazuje da je MS značajan faktor rizika za nastanak i razvoj teže koronarne bolesti.

Ključne reči: metabolički sindrom, infarkt miokarda, koronarografija

\title{
Influence of metabolic syndrome on coronary arteries features in people with myocardial infarction
}

Dusan M. Miljkovic

Primary health care center, Varvarin, Serbia

\section{Abstract}

Introduction: Previous epidemiological and clinical studies confirmed the relation between metabolic syndrome and an increased risk of coronary artery disease (CAD). There was a significant correlation between the syndrome and more severe angiographic lesions in the coronary arteries of these patients.

Objective: We aimed at investigating the importance and influence of the metabolic syndrome on the severity of the angiographic lesions in the coronary arteries of the patients with myocardial infarction.

Method: The research included 143 participants with a myocardial infarction, of whom $81(58.7 \pm 6.2)$ had metabolic syndrome and $62(54.9 \pm 10.3)$ were without it $(\mathrm{p}<0.01)$. Physical examinations, anthropometric measurements, lab results, and coronarography were performed in all patients. To diagnose the metabolic syndrome (MS) we used the American Heart Association's and National Heart Lung and Blood Institute`s criteria.

Results: Participants with MS, when compared to those without MS, had: single-vessel CAD 8,6\% vs 46,8\% $(\mathrm{p}<0,001)$, double-vessel CAD 25,9\% vs 32,3\% ( $>>0,05)$, triple-vessel CAD 65,4\% vs 21,0\% $(\mathrm{p}<0,001)$, multi-vessel CAD $91,3 \%$ vs $53,2 \%(\mathrm{p}<0,001)$. When we compared the affected coronary arteries of the patients with MS and those without MS we found: LAD 88,9\% vs 71,0\% (p<0,01), LCx $64,2 \%$ vs 29,0\% (p<0,01), RCA 80,2\% vs 61,3\% (p<0,01), LM 14,8\% vs 1,6\%.

Conclusion: Patients with MS had more severe coronary artery lesions, with a higher incidence of triple-vessel and multi-vessel disease, as well as stenosis of LAD, LCX. RCA, LM, when compared to those without MS. This clearly indicates MS is a significant risk factor for more severe CAD.

Keywords: Metabolic syndrome, myocardial infarction, coronarography 


\section{Uvod}

\section{Introduction}

Metabolički sindrom (MS) je skup međusobno povezanih fizioloških, biohemijskih, kliničkih i metaboličkih poremećaja, koji direktno i sinergijski povećavaju kardiovaskularni rizik. Takođe, uključuju hiperglikemiju, povišen krvni pritisak, povišene nivoe triglicerida, abdominalnu gojaznost $\mathrm{i}$ smanjen nivo HDL-holesterola ${ }^{1,2}$.

Patofiziološku osnovu MS čine centralna gojaznost i rezistencija na insulin/hiperinsulinemija, praćeni stanjem hronične inflamacije sa endotelnom disfunkcijom, hiperkoagulabilnim stanjem i trombozom ${ }^{3}$.

Prethodna epidemiološka i klinička ispitivanja su potvrdila povezanost između MS i povećanog rizika za nastanak koronarne bolesti ${ }^{4}$. Prevalencija MS u osoba sa akutnim koronarnim sindromom je u različitim studijama od $29 \%$ do $68,4 \%$.

Smatra se da MS povećava rizik za razvoj koronarne bolesti direktnim uticajem na aterosklerotski proces, njegovu progresiju i nestabilnost ${ }^{1}$. Stanje niskog stepena inflamacije i povećan oksidativni stres ubrzavaju aterosklerozu i pogoršavaju koronarnu bolest $\mathrm{u}$ osoba sa $\mathrm{MS}^{1,7}$. Gojaznost i MS karakterišu hipoadiponektinemija i poremećaji metaboličke homeostaze, koji su istovremeno odgovorni za razvoj ateroskleroze kao nezavisnog prediktora kardiovaskularnih događaja $^{7}$.

Pokazano je da se rizik od razvoja koronarne bolesti povećava u prisustvu MS za 7,3 puta kod muškaraca i 10,2 puta kod žena ${ }^{5}$ i da osobe sa MS imaju tri puta veću učestalost obolevanja i dva puta veći rizik smrti od infarkta miokarda $(\mathrm{IM})^{7}$.

Većina studija potvrdila je značajnu povezanost MS sa težim koronarografskim promenama, većom učestalošću trosudovne i višesudovne koronarne bolesti, IM, perkutane koronarne intervencije (PCI) i hirurške revaskularizacije miokarda $(\mathrm{CABG})^{1,8}$.

Rana procena rizika od koronarne bolesti kod pacijenata sa MS je značajna, jer može dovesti do ranije intervencije lekara na njihovo ponašanje, koje će smanjiti rizik za nastanak koronarne bolesti i poboljšati klinički ishod ${ }^{4}$.

\section{Cilj rada}

Cilj rada je bio da se ispita značaj i uticaj metaboličkog sindroma na težinu lezija koronarnih arterija $i$ angiografske karakteristike pacijenata sa prebolelim infarktom miokarda.

\section{Metod}

Ispitivanjem su obuhvaćena 143 bolesnika sa IM, od kojih 81 (58,7 $\pm 6,2$ godine) sa MS i $62(54,9 \pm 10,3$ godine $)$ bez MS, kao kontrolna grupa $(\mathrm{p}<0,01)$.
Metabolic syndrome (MS) is a cluster of interrelated physiological, biochemical, clinical, and metabolic disorders that directly and synergically increase cardiovascular risk. It also includes hyperglycemia, hypertension, hypertriglyceridemia, abdominal obesity, and lower levels of HDL-cholesterol. ${ }^{1,2}$

The pathophysiologic core of MS are central obesity and insulin resistance (hyperinsulinemia), followed by chronic inflammation with endothelial dysfunction, hypercoagulative state, and thrombosis. ${ }^{3}$

Previous epidemiological and clinical studies confirmed the relation between metabolic syndrome and an increased risk of coronary artery disease (CAD) ${ }^{4}$ Prevalence of MS, in patients with acute coronary syndrome varies in different studies from $29 \%$ to $68.4 \%$. $^{5.6}$

MS is considered to increase the risk for CAD by directly influencing the atherosclerotic process, its progression, and instability ${ }^{1}$. The state of a low level of inflammation and increased oxidative stress speed up atherosclerosis and deteriorate CAD in patients with MS..$^{1,7}$ Obesity and MS include hypoadiponectinemia and metabolic homeostasis disorder. At the same time, they are responsible for the development of atherosclerosis as an independent predictor of cardiovascular events. ${ }^{7}$

It's been proved the risk of CAD increases in the presence of MS, 7.3 times in men and 10.2 times in women ${ }^{5}$, and patients with MS have got three times higher incidence of myocardial infarction (MI) and two times higher risk of dying of MI. ${ }^{7}$

The majority of studies confirmed an important connection between MS and severe forms of CAD, as well as a higher incidence of triple and multi-vessel CAD, MI, percutaneous coronary intervention (PCI) and surgical myocardial revascularization $(\mathrm{CABG}){ }^{1,8}$

Early risk assessment for CAD in patients with MS is very important because it may lead to physician's earlier intervention. This may influence a patient's behavior to lower the risk of CAD and improve the clinical outcome. ${ }^{4}$

\section{Objective}

We aimed at investigating the importance and influence of the metabolic syndrome on the severity of the angiographic lesions in the coronary arteries of the patients with myocardial infarction.

\section{Method}

Our study included 143 patients with MI, of whom 81 (58.7 \pm 6.2 years) with MS and $62(54.9 \pm 10.3$ years) without $\mathrm{MS}$, as a control group $(\mathrm{p}<0.01)$. 
Primenjeno je opservaciono istraživanje-studija preseka u periodu od 2010 do 2017. godine. Kod svih obolelih uzeta je detaljna lična i porodična anamneza, obavljeni klinički pregledi, antropometrijska merenja, stalna elektrokardiografska dijagnostika i koronarografija.

Kompletno kardiološko i hemodinamsko ispitivanje, kateterizacija srca sa selektivnom koronarografijom i revaskularizacijom miokarda, CABG ili PCI, obavljeni su u Institutu za kardiovaskularne bolesti Kliničkog centra Srbije i Institutu za kardiovaskularne bolesti Dedinje u Beogradu. Manji broj koronarografija i PCI obavljen je u Kliničkim centrima Niš i Kragujevac.

Značajna stenoza koronarnih sudova definisana je kao: prisustvo suženja lumena unutrašnjeg prečnika $\geq 50 \%$, u jednoj ili više koronarnih arterija, i klasifikovana kao jednosudovna, dvosudovna, trosudovna i višesudovna bolest.

Stanje uhranjenosti ocenjeno je na osnovu antropometrijskih parametara (telesna visina, telesna težina, obim struka). Stepen uhranjenosti procenjen je na osnovu vrednosti indeksa telesne mase (ITM $\mathrm{kg} / \mathrm{m}^{2}$ ).

Ukupni holesterol i trigliceridi (TG) određivani su metodom oksidaza/peroksidaza, LDL i HDL-holesterol Direct metodom, glikemija metodom glukoza oksidaza/peroksidaza. Sve analize su urađene na aparatu: Biohemijski analizator A15 Bio Systems, korišćenjem reagenasa Bio Systems.

Za postavljanje dijagnoze MS korišćeni su kriterijumi Američkog udruženja za srce i Nacionalnog instututa za srce, pluća i krv (AHA/NHLBI). Metabolički sindrom su imali pacijenti koji su ispunjavali najmanje tri od sledećih pet kriterijuma: hipertrigliceridemija ( $\mathrm{TG}>1,7 \mathrm{mmol} / \mathrm{L})$, nizak HDL-holesterol $(<1,03 \mathrm{mmol} / \mathrm{L}$ kod muškaraca i $<1,29$ $\mathrm{mmol} / \mathrm{L}$ kod žena), sistolni pritisak $>130 \mathrm{mmHg}$ i/ili dijastolni pritisak $>85 \mathrm{mmHg}$, glikemija natašte $>5,6 \mathrm{mmol} / \mathrm{L}$ i obim struka $>102 \mathrm{~cm}$ kod muškaraca i $>88 \mathrm{~cm}$ kod žena 9 .

U statističkoj analizi podataka korišćeni su deskriptivni i analitički metodi. Od deskriptivnih metoda korišćeni su srednja vrednost (SV) i standardna devijacija (SD). Od analitičkih statističkih metoda korišćeni su Studentov t-test i $\chi^{2}$ test. Dobijeni rezulati prikazani su tabelarno.

\section{Rezultati}

Osnovne karakteristike i vrednosti pojedinačnih komponenata ispitanika sa i bez MS, prikazani su na Tabeli 1.
We used observational research-a cross-sectional study during the 2010-2017 period. We took patients` thorough personal and family history, performed clinical examination and anthropometric measurements, electrocardiography (ECG), and coronarography.

Complete cardiologic and hemodynamic examination, heart catheterization with selective coronarography, and myocardial revascularization (CABG or $\mathrm{PCI}$ ) were performed at the Institute for cardiovascular diseases of the Clinical Center of Serbia and the Institute for cardiovascular diseases, Dedinje, Belgrade. A smaller number of the coronarographies and PCIs were performed in the Clinical Centers Nis and Kragujevac.

Severe coronary artery stenosis was defined as: the stenosis of the artery's inside diameter $\geq 50 \%$, in one or more arteries, which was classified as a single, double, triple, or multi-vessel disease. The nutritional status was assessed by anthropometric parameters (body weight, height, waist circumference). The nutritional level was assessed by calculating body mass index $\left(\mathrm{BMI}, \mathrm{kg} / \mathrm{m}^{2}\right)$.

Total cholesterol and triglycerides were measured using oxidase/peroxidase method, LDL and HDL-cholesterol using the direct method, and glycemia using glucose oxidase/ peroxidase method. All lab analyses were performed in Biochemical analyzer A15, Byo Systems, using Byo System`s reagents.

To diagnose MS, we used the American Heart Association`s and National Heart Lung and Blood Institute's criteria (AHA/NHLBI). Metabolic syndrome was diagnosed in patients with at least three out of five criteria: hypertriglyceridemia $(\mathrm{Tg}>1.7 \mathrm{mmol} / \mathrm{l})$, low HDL-cholesterol $(<1.03$ $\mathrm{mmol} / 1$ in men and $<1.29 \mathrm{mmol} / \mathrm{l}$ in women), systolic blood pressure $>130 \mathrm{mmHg}$ and/or diastolic blood pressure $>85$ $\mathrm{mmHg}$, fasting glucose $>5.6 \mathrm{mmol} / \mathrm{l}$, and waist circumference $>102 \mathrm{~cm}$ in men and $88 \mathrm{~cm}$ in women. ${ }^{9}$

We used descriptive and analytical methods for statistical data analysis. The descriptive methods we used were the mean value (MV) and standard deviation (SD). The analytical methods we used were Student's t-test and $\chi^{2}$ test. All the results are shown in the tables.

\section{Results}

The basic characteristics and values of the single components of the patients with or without MS are shown in Table 1. 
Tabela 1. Osnovne karakteristike ispitanika i vrednosti komponenti metaboličkog sindroma

Table 1. Basic characteristics of the participants and MS components`values

\begin{tabular}{|c|c|c|c|c|c|}
\hline \multirow[t]{2}{*}{$\begin{array}{l}\text { Parametri } \\
\text { Parameters }\end{array}$} & \multicolumn{2}{|c|}{$\begin{array}{c}\text { Sa metaboličkim sindromom } \\
\text { With metabolic syndrome } \\
(\mathrm{N}=81)\end{array}$} & \multicolumn{3}{|c|}{$\begin{array}{l}\text { Bez metaboličkog sindroma } \\
\text { Without metabolic syndrome } \\
(\mathrm{N}=62) \\
\end{array}$} \\
\hline & $\mathbf{X}$ & SD & $\mathbf{X}$ & SD & $\mathbf{p}$ \\
\hline Godine života / Age & 58,7 & 5,2 & 54,9 & 10,3 & $<0,01$ \\
\hline $\begin{array}{l}\text { Pol / Gender } \\
\text { Muškarci / Male } \\
\text { Žene / Female }\end{array}$ & \multicolumn{2}{|c|}{$\begin{array}{l}63(77,8 \%) \\
18(22,2 \%)\end{array}$} & \multicolumn{2}{|c|}{$\begin{array}{l}49(79 \%) \\
13(21 \%)\end{array}$} & $>0,05$ \\
\hline $\operatorname{BMI}\left(\mathrm{kg} / \mathrm{m}^{2}\right)$ & 29,7 & 3,4 & 25,7 & 1,9 & $<0,001$ \\
\hline Obim struka $(\mathrm{cm}) /$ Waist circumference & 104,9 & 14,8 & 85,1 & 16,1 & $<0,001$ \\
\hline Glikemija / Glycemia $(\mathrm{mmol} / \mathrm{L})$ & 9,9 & 4,6 & 6,3 & 1,2 & $<0,001$ \\
\hline Ukupni holesterol / Total cholesterol $(\mathrm{mmol} / \mathrm{L})$ & 6,5 & 2,1 & 5,7 & & $<0,01$ \\
\hline Trigliceridi / Tryglicerides $(\mathrm{mmol} / \mathrm{L})$ & 4,1 & 4,4 & 1,5 & 0,7 & $<0,001$ \\
\hline HDL-holesterol / HDL-cholesterol $(\mathrm{mmol} / \mathrm{L})$ & 1,0 & 0,4 & 1,2 & 0,4 & $<0,01$ \\
\hline LDL-holesterol / LDL-cholesterol $(\mathrm{mmol} / \mathrm{L})$ & 3,8 & 1,5 & 3,0 & 1,5 & $<0,001$ \\
\hline $\begin{array}{l}\text { Krvni pritisak / Blood pressure } \\
\text { Sistolni / Systolic }(\mathrm{mmHg}) \\
\text { Dijastolni / Diastolic }(\mathrm{mmHg})\end{array}$ & $\begin{array}{l}46,1 \\
87,5\end{array}$ & $\begin{array}{l}24,7 \\
14,2\end{array}$ & $\begin{array}{c}137,4 \\
82,2\end{array}$ & $\begin{array}{l}21,6 \\
10,4\end{array}$ & $\begin{array}{l}<0,05 \\
<0,05\end{array}$ \\
\hline Trigliceridi / Tryglicerides $>1,7 \mathrm{mmol} / \mathrm{L}$ & \multicolumn{2}{|c|}{$60(74,1 \%)$} & \multicolumn{2}{|c|}{$20(3,2 \%)$} & $<0,001$ \\
\hline $\begin{array}{l}\text { HDL-holesterol } / \mathrm{HDL} \text {-cholesterol } \\
<1,03 / 1,29 \mathrm{mmol} / \mathrm{L}\end{array}$ & \multicolumn{2}{|c|}{$59(72,8 \%)$} & \multicolumn{2}{|c|}{$17(27,4 \%)$} & $<0,001$ \\
\hline
\end{tabular}

Učestalost znatnih stenoza pojedinačnih koronarnih arterija, trosudovne i višesudovne bolesti, prikazani su na Tabeli 2 .
The incidence of the severe stenoses of the singular coronary arteries, triple and multi-vessel disease, are shown in Table 2.

Tabela 2. Učestalost jednosudovne, dvosudovne, trosudovne i višesudovne bolesti i pojedinačnih koronarnih arterija sa značajnim stenozama kod osoba sa infarktom miokarda sa i bez metaboličkog sindroma

Table 2. The incidence of single, double, triple and multi-vessel disease and singular coronary arteries with significant stenoses in patients with myocardial infarction and with/without metabolic syndrome

\begin{tabular}{|c|c|c|c|c|c|}
\hline \multirow[t]{2}{*}{$\begin{array}{l}\text { Bolest koronarnih sudova } \\
\text { Coronary artery disease }\end{array}$} & \multicolumn{2}{|c|}{$\begin{array}{c}\text { Sa metaboličkim sindromom } \\
\text { With metabolic syndrome } \\
(\mathrm{N}=81)\end{array}$} & \multicolumn{3}{|c|}{$\begin{array}{l}\text { Bez metaboličkog sindroma } \\
\text { Without metabolic syndrome } \\
\qquad(\mathrm{N}=62)\end{array}$} \\
\hline & Broj/Number & $\%$ & Broj/Number & $\%$ & $\mathbf{p}$ \\
\hline Jednosudovna bolest / Single-vessel disease & 7 & 8,6 & 29 & 46,8 & $<0,001$ \\
\hline Dvosudovna bolest / Double-vessel disease & 21 & 25,9 & 20 & 32,3 & $>0,05$ \\
\hline Trosudovna bolest / Triple-vessel disease & 53 & 65,4 & 13 & 21,0 & $<0,001$ \\
\hline Višesudovna bolest / Multi-vessel disease & 74 & 91,3 & 33 & 53,2 & $<0,001$ \\
\hline LAD & 72 & 88,9 & 44 & 71,0 & $<0,01$ \\
\hline LCX & 52 & 64,2 & 18 & 29,0 & $<0,01$ \\
\hline RCA & 65 & 80,2 & 38 & 61,3 & $<0,01$ \\
\hline LAD proksimalna stenoza / LAD proximal stenosis & 38 & 46,9 & 23 & 37,1 & $>0,05$ \\
\hline LCD proksimalna stenoza / LCD proximal stenosis & 29 & 35,8 & 4 & 6,5 & $<0,01$ \\
\hline RCA proksimalna stenoza / RCA proximal stenosis & 32 & 39,5 & 15 & 24,2 & $<0,05$ \\
\hline Bolest glavnog stabla (LM) / Left main disease (LM) & 12 & 14,8 & 1 & 1,6 & - \\
\hline
\end{tabular}


Dijabetičari sa MS u odnosu na nedijabetičare sa MS, imaju neznatno veću učestalost trosudovne $67,8 \%$ vs 59,1\% ( $\mathrm{p}>0,05)$ i višesudovne bolesti 94,9\% vs 81,8\% ( $>>0,05)$.

Nedijabetičari sa MS u poređenju sa onima bez MS, imaju znatno veću učestalost trosudovne 59,1\% vs 21,0\% $(\mathrm{p}<0,01)$ i višesudovne bolesti $81,8 \%$ vs $53,2 \%(\mathrm{p}<0,01)$ i neznatno viši nivo glikemije $6,5 \pm 0,8 \mathrm{mmol} / \mathrm{L}$ vs $6,3 \pm 1,2 \mathrm{mmol} / \mathrm{L}$ $(\mathrm{p}>0,05)$.

Ukupan broj proksimalnih stenoza prednje descendenthe arterije (LAD) + leve cirkumfleksne arterije (LCX) + desne koronarne arterije (RCA) je 99 kod ispitanika sa MS ili 1,22 suda po osobi i 42 kod onih bez MS ili 0,67 suda po osobi.

Ukupan broj koronarnih sudova sa značajnom stenozom kod ispitanika sa MS je 266 ili 3,28 suda po ispitaniku, a bez MS 128 ili 2,06 suda po ispitaniku. Kliničke karakteristike ispitanika sa i bez MS, prikazane su na Tabeli 3.
Diabetic patients with MS, unlike non-diabetics with MS, have slightly higher incidence of triple-vessel CAD $67.8 \%$ vs 59.1\% ( $>0.05)$ and multi-vessel CAD 94.9\% vs $81.8 \%(\mathrm{p}>0.05)$.

Non-diabetics with MS, unlike non-diabetics without MS, are at much higher risk of triple-vessel CAD $59.1 \%$ vs 21,0\% $(\mathrm{p}<0.01)$ and multi-vessel CAD $81.8 \%$ vs $53.2 \%$ $(\mathrm{p}<0.01)$ and slightly higher glycemic levels $6.5 \pm 0.8 \mathrm{mmol} / \mathrm{l}$ vs $6.3 \pm 1.2 \mathrm{mmol} / \mathrm{l}(\mathrm{p}>0.05)$.

The total number of proximal stenoses of the anterior descendent artery (LAD) + left circumflex artery (LCX) + right coronary artery (RCA) is 99 , in patients with MS, or 1.22 vessels/person. In those without MS, it`s 42 , or 0.67 vessels/person.

A total number of coronary arteries with significant stenoses in patients with MS was 266, or 3.28 vessels/person and without MS 128 or 2.06 vessels/person.

Clinical characteristics of the participants, with or without MS, are shown in Table 3.

Tabela 3. Kliničke karakteristike i načini lečenja bolesnika sa infarktom miokarda sa i bez metaboličkog sindroma

Table 3. Clinical features and treatment strategy in patients with myocardial infarction and without metabolic syndrome

\begin{tabular}{|c|c|c|c|c|c|}
\hline & \multicolumn{2}{|c|}{$\begin{array}{c}\text { Sa metaboličkim sindromom } \\
\text { With metabolic syndrome } \\
(\mathrm{N}=81)\end{array}$} & \multicolumn{3}{|c|}{$\begin{array}{l}\text { Bez metaboličkog sindroma } \\
\text { Without metabolic syndrome } \\
(\mathrm{N}=62)\end{array}$} \\
\hline & Broj/Number & $\%$ & Broj/Number & $\%$ & $\mathbf{p}$ \\
\hline Prednji infarkt / Anterior MI & 45 & 55,5 & 30 & 48,4 & $>0,05$ \\
\hline Donji infarkt / Inferior MI & 28 & 34,6 & 21 & 33,9 & $>0,05$ \\
\hline Prednji-donji infarkt / Anterior-inferior $M I$ & 8 & 9,9 & 11 & 17,7 & $>0,05$ \\
\hline STEMI & 62 & 76,5 & 44 & 71 & $>0,05$ \\
\hline $\begin{array}{l}\text { Ejekciona frakcija leve komore } \\
\text { Ejection fraction of left ventricle ( } \mathrm{EF} \% \text { ) }\end{array}$ & \multicolumn{2}{|c|}{$44,3 \pm 11,1 \%$} & \multicolumn{2}{|c|}{$48,9 \pm 9,8 \%$} & $<0,001$ \\
\hline $\begin{array}{l}\text { Poremećaji ritma i sprovođenja } \\
\text { Rhythm and conduction abnormalities }\end{array}$ & 26 & 32,1 & 8 & 12,9 & $<0,01$ \\
\hline Reinfarkt / Re-infarction & 25 & 30,8 & 6 & 9,7 & $<0,01$ \\
\hline C A B G & 42 & 51,8 & 12 & 19,3 & $<0,01$ \\
\hline $\mathrm{P} \mathrm{C} \mathrm{I}$ & 27 & 33,3 & 43 & 69,3 & $<0,01$ \\
\hline Medikamentna terapija /Drug therapy & 10 & 12,3 & 6 & 9,7 & $>0,05$ \\
\hline $\mathrm{PCI}+\mathrm{CABG}$ & 2 & 2,5 & 1 & 1,6 & - \\
\hline Srčana Insuficijencija / Heart failure & 18 & 22,2 & 4 & 6,5 & $<0,01$ \\
\hline
\end{tabular}

Od pojedinačnih lokalizacija IM najčešća je, u obe grupe ispitanika, dijafragmalna 30,9\% vs 29,0\% (p>0,05), zatim anteriorna $24,9 \%$ vs $19,3 \%(\mathrm{p}>0,05)$ i anteroseptalna $23,5 \%$ vs 19,4\% ( $>>0,05)$. Učestalost faktora rizika koronarne bolesti prikazana je na Tabeli 4.
As for the location of MIs, the most common, in both groups, is diaphragmal 30.9\% vs 29.0\% ( $\mathrm{p}>0.05)$, anterior $24.9 \%$ vs $19.3 \%(\mathrm{p}>0.05)$ and anteroseptal $23.5 \%$ vs $19.4 \%$ $(\mathrm{p}>0.05)$. The incidence of risk factors for CAD is shown in Table 4. 
Tabela 4. Učestalost faktora rizika koronarne bolesti u osoba sa infarktom miokarda sa i bez metaboličkog sindroma

Table 4. Incidence of risk factors for CAD in patients with MI and without metabolic syndrome

\begin{tabular}{|c|c|c|c|c|c|}
\hline \multirow[t]{2}{*}{$\begin{array}{l}\text { Bolest koronarnih sudova } \\
\text { Coronary artery disease }\end{array}$} & \multicolumn{2}{|c|}{$\begin{array}{c}\text { Sa metaboličkim sindromom } \\
\text { With metabolic syndrome } \\
(\mathrm{N}=81)\end{array}$} & \multicolumn{3}{|c|}{$\begin{array}{l}\text { Bez metaboličkog sindroma } \\
\text { Without metabolic syndrome } \\
\qquad(\mathrm{N}=62)\end{array}$} \\
\hline & Broj/Number & $\%$ & Broj/Number & $\%$ & $\mathbf{p}$ \\
\hline Arterijska hipertenzija / Arterial hypertension & 77 & 95,1 & 43 & 69,4 & $<0,01$ \\
\hline Dijabetes melitus / Diabetes mellitus & 59 & 72,8 & 8 & 12,9 & $<0,001$ \\
\hline Hiperlipidemija / Hyperlipidemia & 75 & 92,6 & 44 & 71,0 & $<0,01$ \\
\hline Pušenje / Smoking & 45 & 55,6 & 41 & 66,1 & $>0,05$ \\
\hline Hereditet / Heredity & 29 & 35,8 & 29 & 46,8 & $>0,05$ \\
\hline
\end{tabular}

\section{Diskusija}

Istraživanje je pokazalo da osobe sa MS imaju težu koronarnu bolest sa značajno većom učestalošću trosudovne i višesudovne bolesti, ukupnim brojem značajnih stenoza i proksimalnih stenoza koronarnih arterija, u poređenju sa osobama bez MS.

Ranije studije ukazuju na značaj i potencijal sinergijskih efekata komponenti MS na razvoj i ubrzanje procesa ateroskleroze i koronarne bolesti kao posledice inflamacije uzrokovane MS, koja ima važnu ulogu u ovom procesu ${ }^{7,9}$.

Naši ispitanici sa MS imali su značajno viši nivo triglicerida i niži nivo HDL-holesterola u odnosu na ispitanike bez MS, što je zapaženo i u drugim studijama ${ }^{4,9,10,11}$. Visoke koncentracije triglicerida i niske HDL-holesterola identifikuju osobe sa rezistencijom na insulin i snažan su pokazatelj rezistencije na insulin/hiperinsulinemije, koja je sama po sebi kardiovaskularni faktor rizika ${ }^{12}$.

Osim povećane koncentracije serumskih triglicerida $\mathrm{i}$ učestalost hipertrigliceridemija kod naših ispitanika sa MS je visoka $(73,5 \%)$, u odnosu na nalaze drugih studija $37,5 \%$, $38,5 \%{ }^{1}, 59,1 \%{ }^{11}, 64,1 \%{ }^{13}$, ali niža u odnosu na neka druga istraživanja $(81,6 \%)^{14}$.

Trigliceridi imaju značajnu ulogu u aterogenezi, trombogenezi i prokoagulantnom stanju ${ }^{15,16}$, a više prospektivnih, epidemioloških studija ukazuje na pozitivnu povezanost između povišenih vrednosti triglicerida i koronarne bolesti ${ }^{17}$. Dokazano je da hipertrigliceridemija predskazuje rizik koronarne bolesti nezavisno od ostalih faktora rizika, uključujući LDL i HDL-holesterol $^{18}$.

Rezultati istraživanja pokazuju značajno nižu koncentraciju i visoku frekvenciju nižih vrednosti HDL-holesterola kod pacijenata sa MS, što nalaze i druge studije, 31,9\% ${ }^{1}$, $45 \%{ }^{5}, 52,5 \%{ }^{9}, 77,3 \% 0^{11,14}, 84,8 \%{ }^{19}, 87,6 \%{ }^{13}$.

\section{Discussion}

The research proved patients with MS had more severe CAD, with a higher frequency of triple and multi-vessel disease, the total number of significant stenoses, and proximal stenoses of the coronary arteries, when compared to patients without MS.

Previous studies have pointed to the importance and potential of the synergic effects of MS components on development and speeding up the atherosclerotic process and CAD, as a consequence of inflammation caused by MS. MS has got an important role in the process. ${ }^{7,9}$

Our participants with MS had a significantly higher level of triglycerides and lower levels of HDL-cholesterol when compared to those without MS, and the same was confirmed in other numerous studies. ${ }^{4,9,10,11}$ High levels of triglycerides and low levels of HDL-cholesterol identify the patients with insulin resistance and are a strong predictor of insulin resistance/hyperinsulinemia, which in itself is a cardiovascular risk factor. ${ }^{12}$

Besides higher levels of triglycerides, the incidence of hypertriglyceridemia in our patients with MS was high $(73.5 \%)$, when compared to other study findings $37.5 \%$, $38.5 \%{ }^{1}, 59.1 \%{ }^{11}, 64.1 \%{ }^{13}$, but also lower when compared to some other studies $(81.6 \%)^{14}$.

Triglycerides have an important role in atherogenesis, thrombogenesis, and procoagulant states. ${ }^{15.16}$ Several prospective, epidemiologic studies showed the positive correlation between high levels of triglycerides and CAD $.{ }^{17} \mathrm{Hy}-$ pertriglyceridemia predicts the risk of $\mathrm{CAD}$, independent of other risk factors, including LDL and HDL-cholesterol. ${ }^{18}$

Our research results point to a significantly lower concentration and a higher incidence of low levels of HDL-cholesterol in patients with MS, which was found in some other studies as well, $31,9 \%{ }^{1}, 45 \% 0^{5}, 52.5 \% 0^{9}, 77.3 \%{ }^{11,14}, 84.8 \%{ }^{19}$, $87.6 \%{ }^{13}$. 
U prethodnim istraživanjima pokazana je značajna povezanost između niskog nivoa HDL-holesterola i povećanog rizika za koronarnu bolest ${ }^{17} \mathrm{i}$ potvrđeno da je nizak HDL-holesterol najznačajniji parametar koji utiče na težinu koronarne bolesti ${ }^{8,13,16}$.

Udruženost veće koncentracije triglicerida i manje HDL-holesterola, kao markera povećanog kardiovaskularnog rizika, poznatog kao aterogena dislipidemija uz njihovu visoku frekventnost i uz ostale komponente MS, doprinose težoj koronarnoj bolesti kod pacijenata sa MS.

Naši ispitanici sa MS imali su znatno viši nivo glikemije u poređenju sa onima bez MS. Istraživanja su pokazala da je hiperglikemija najbitnija komponenta koja doprinosi prediktivnoj snazi rizika koronarne bolesti kod osoba sa $\mathrm{MS}^{20} \mathrm{i}$ da je sama jači predskazivač ove bolesti, u opštoj populaciji, od MS u celini ili bilo koje od njegovih pojedinačnih komponenti $^{10,16,21,22}$.

Učestalost dijabetesa kod naših ispitanika sa MS je visoka u poređenju sa nalazima drugih studija gde je ona registrovana kod $40 \%{ }^{5}, 46,7 \%^{1}, 56,8 \%{ }^{23} 59,6 \%{ }^{24}, 66,6 \%^{13}$ i značajno je povezana sa koronarnom bolešću.

Smatra se da je povišen rizik koji nosi MS najvećim delom u vezi sa dijabetesom, jer su neka istraživanja pokazala da je kod nedijabetičara sa MS nađen neznatno povećan rizik od kardiovaskularnih bolesti ${ }^{12,25}$.

Naši nalazi su, međutim, pokazali da je grupa nedijabetičara sa MS imala težu koronarnu bolest, u poređenju sa osobama bez MS i onda kada je među njima bilo i dijabetičara, i govori o značaju MS kao jedinstvenom dopunskom sistemu elemenata i snažnom faktoru rizika koronarne bolesti. Ovo podržavaju nalazi neznatno veće učestalosti trosudovne i višesudovne bolesti u našoj grupi dijabetičara sa MS, u poređenju sa grupom nedijabetičara sa MS.

Dokazano je da dijabetičari imaju angiografski težu koronarnu bolest i veću prevalenciju difuzne i ekstenzivne koronarne ateroskleroze, uključujući i kalcifikaciju koronarnih $\operatorname{arterija~}^{4,6,26}$; na to ukazuje i značajno veća učestalost trosudovne i višesudovne bolesti u grupi naših dijabetičara sa MS, u poređenju sa onima bez $\mathrm{MS}^{27}$.

Značaj dijabetesa i hiperglikemije u razvoju koronarne bolesti kod osoba sa MS, potvrđuju i nalazi Bonamikija i sar. (Bonamichi $)^{28}$ da su teže koronarne lezije, sa stenozama većim od 70\%, značajno češće u dijabetičara sa MS, u odnosu na nedijabetičare sa MS ( $74 \%$ vs $22 \%)$, što pokazuje da osim rezistencije na insulin koja postoji u MS i dijabetesu tip 2, sama hiperglikemija može imati uticaj na patogenezu aterosklerotske bolesti ${ }^{28}$.

Dosadašnja istraživanja su pokazala da pored hiperglikemije, niskog HDL-holesterola i hipertenzija predstavlja visok rizik za nastanak koronarne bolesti ${ }^{10,16,20}$, što je u vezi sa nalazima značajno većih vrednosti sistolnog i dijastolnog pritiska $^{23} \mathrm{i}$ učestalosti hipertenzije $\mathrm{u}$ naših ispitanika sa MS, u poređenju sa onima bez MS.
The previous research showed the significant correlation between low level of HDL-cholesterol and an increased risk for CAD. ${ }^{17}$ It's confirmed that the low level of HDLcholesterol is the most important parameter to influence the severity of CAD. ${ }^{8,13,16}$

A combination of the high level of triglycerides and low level of HDL-cholesterol, as a marker for increased CV risk, also known as the atherogenic dislipidemia, combined with their high frequency and other MS components, leads to more severe CAD in patients with MS.

Our participants with MS had a significantly higher level of glycemia when compared to those without MS. The previous studies confirmed hyperglycemia is the most important component in predicting the risk of CAD in patients with MS. ${ }^{20}$ Hyperglycemia, alone, is the stronger predictor of $\mathrm{CAD}$ in the general population than MS, as a whole, or any other of its singular components. . $^{1016,21,22}$

The incidence of diabetes in our participants with MS was high when compared to other studies, $40 \%{ }^{5}, 46.7 \%^{1}$, $56.8 \%{ }^{23} 59.6 \%{ }^{24}, 66.6 \%{ }^{13}$ and it has a significant connection to $\mathrm{CAD}$.

It's believed the higher risk MS bears is mostly due to its connection to diabetes. Some studies actually showed non-diabetics with MS had just a slightly higher risk of CV disease. ${ }^{12,25}$

Our results, on the other hand, showed non-diabetics with MS had severe forms of CAD, when compared to patients without MS, even when there were diabetics among those without MS. It, in itself, speaks of the importance of MS, as a unique complementary system of components and a strong risk factor for CAD. This statement is supported by the findings of a slightly higher incidence of triple and multiplevessel disease in our group of diabetics with MS, when compared with the group of non-diabetics with MS.

It's already proved diabetics have got more severe angiography findings and a higher prevalence of a diffuse and extensive coronary atherosclerosis, including the calcification of coronary arteries. ${ }^{4,6,26}$ It's also proved through a significantly higher incidence of the triple and multi-vessel disease in the group of our diabetics with MS than the patients without MS. ${ }^{27}$

The importance of diabetes and hyperglycemia in CAD, in patients with MS, is confirmed in the findings of Bonamichi at all. ${ }^{28} \mathrm{He}$ showed the more severe coronary artery lesions, with stenosis more than $70 \%$, were significantly more common in diabetics with MS, when compared to non-diabetics with MS ( $74 \%$ vs $22 \%)$, which clearly shows that beside insulin resistance, which is found in MS and diabetes type 2, the hyperglycemia, by itself, may influence the pathogenesis of the atherosclerotic disease. ${ }^{28}$

Up-to-date research showed, beside hyperglycemia and low HDL-cholesterol, hypertension is also a huge risk factor for CAD. ${ }^{10.16 .20}$ It's in correlation with the findings of higher values of systolic and diastolic BP values ${ }^{23}$ and the incidence of hypertension in our patients with MS, than in those without MS. 
Učestalost hipertenzije kod naših ispitanika sa MS, bila je veća u odnosu na nalaze većine drugih studija ${ }^{1,5,9}$, ali je sa nalazima pojedinih bila uporediva ${ }^{2,10,14}$ i kretala se u rasponu od $55,8 \% \%^{24}, 58 \%{ }^{5}, 61,1 \%^{13}, 64,1 \%^{26}, 69,3 \%{ }^{11}, 71,2 \%^{23}$, $79,7 \%{ }^{9}, 95,6 \%^{2}$, do $98,7 \%{ }^{14}$.

Grupe naših ispitanika bile su homogene po polu, navici pušenja, hereditetu i uporedive sa nalazima drugih studi$\mathrm{ja}^{1,2,9,11,13}$. Nisu postojale značajne međugrupne razlike u učestalosti IM sa ST-elevacijom (STEMI) i lokalizaciji infarkta, mada su u većem procentu zastupljeniji u MS. Nepostojanje značajnih razlika u učestalosti pušenja i herediteta, između osoba sa/bez MS, pokazuje da ovi faktori rizika nisu značajno uticali na razlike u težini koronarne bolesti, što je u saglasnosti sa rezultatima drugih studija ${ }^{13}$.

Pokazana je visoka učestalost STEMI u pacijenata sa MS, u poređenju sa nalazima većine drugih istraživanja, $41,8 \%{ }^{9}, 42,8 \%{ }^{1}$, u kojima je infarkt miokarda bez ST-elevacije (NSTEMI) dijagnostikovan, suprotno našim nalazima, češće kod onih bez $\mathrm{MS}^{1,2,9,13}$. U manjem broju studija pokazana je učestalost STEMI $(71,2 \%)$ uporediva sa našim nalazima ${ }^{23}$.

Osim toga, zapažena je i veća učestalost IM prednjeg zida kod naših ispitanika, u odnosu na druga istraživanja gde je nađena u $40,1 \%{ }^{9}$ s, $42 \%{ }^{27}, 49 \%{ }^{5}$ slučajeva.

Učestalost muškaraca u odnosu na žene, u obe grupe, bila je 3,5 do 3,7 puta veća, sa približno jednakim odnosom muškaraca i žena i saglasna je većini studija koje, takođe, nalaze veću učestalost muškaraca u MS $S^{1,2,3,5,11,23,27}$. Druga istraživanja, međutim, nalaze dominantnost žena u MS M, $14,19,24,29^{2}$.

Ispitanci sa MS su bili znatno stariji u odnosu na one bez MS, što je zapaženo i u drugim studijama ${ }^{1,9,11,29}$, a s obzirom na snažnu ulogu starosti kao faktora povećanog rizika za MS i koronarnu bolest, pokazanu u ranijim istraživanjima ${ }^{3}$, ovo treba uzeti u obzir pri proceni dobijenih rezultata ${ }^{24}$.

Naši ispitanici sa MS imali su značajno veću učestalost poremećaja ritma i sprovođenja, reinfarkta miokarda, nižu ejekcionu frakciju leve komore (EF) i češće srčanu insuficijenciju (SI), u odnosu na pacijente kontrolne grupe, bez MS, što kod njih ukazuje na postojanje teže koronarne bolesti.

Prosečna vrednost EF u našoj grupi sa MS bila je niža u poređenju sa nalazima drugih istraživanja $47,3 \%{ }^{1}, 49,7 \%{ }^{9}$, $50,0 \%{ }^{2}, 50,6 \%{ }^{14}$, i ukazuje na veći obim oštećenja miokarda. U vezi je sa nalazom značajno češće SI kod ovih bolesnika, što je zapaženo i u drugim studijama².

Ovi nalazi pokazuju da je rezultanta negativnih uticaja komponenti MS, rezistencije na insulin, dijabetesa i abnormalnosti lipida na učestalost, težinu i razvoj SI, kod naših ispitanika, prevagnula u odnosu na pozitivne uticaje koje imaju na SI druge komponente MS - prekomerna težina, odnosno paradoks gojaznosti i visok krvni pritisak ${ }^{30}$.

Povezanost MS sa težinom koronarne bolesti pokazana je i u drugim istraživanjima ${ }^{1,3,27}$. Nađeno je da je učestalost višesudovne bolesti značajno veća kod ispitamika sa MS i IM, $\mathrm{u}$ odnosu na ispitanike sa IM bez MS, da se kretala u rasponu
The incidence of hypertension in our participants with MS was higher than in some studies` findings ${ }^{1,5,9}$, but it was comparable to the findings of the other studies ${ }^{2.10,14}$ and it ranged from $55.8 \%^{24}, 58 \% \%^{5}, 61.1 \%^{13}, 64.1 \%^{26}, 69.3 \%{ }^{11}$, $71.2 \%^{23}, 79.7 \%^{9}, 95.6 \%^{2}$, to $98.7 \%{ }^{14}$.

The groups of our participants were homogenous in gender, smoking habits, heredity, and comparable to the findings from other studies. ${ }^{1,2,9,11,13}$ There were no significant intergroup differences, as far as the incidence of MI with STelevation (STEMI) and localization of MI were concerned, although they were more common in MS. There were no significant differences in the incidence of smoking and heredity between patients with/without MS, which shows these risk factors didn't significantly influence the difference in the severity of CAD, which is in correlation with the results of other studies. ${ }^{13}$

There was a high incidence of STEMI in patients with MS when compared to the findings of the majority of other studies $41.8 \%{ }^{9}, 42.8 \%{ }^{1}$, in which MI without ST elevation (NSTEMI) was diagnosed, contrary to our findings, more frequently in those without MS. ${ }^{1.29 .13}$ In the smaller number of studies the incidence of STEMI (71.2\%) was comparable to our findings. ${ }^{23}$

Besides, we noticed the higher incidence of the anterior wall MI in our participants when compared to other studies where the incidence was $40.1 \%{ }^{9}, 42 \%{ }^{27}, 49 \%{ }^{5}$.

The incidence of men, when compared to women, in both groups, was 3.5 to 3.7 times higher, with an approximately equal ratio of men and women. It correlates with the results of the majority of studies which also found a higher incidence of men in MS. ${ }^{1,2,3,5,11,23,27}$ On the other hand, other studies found a higher incidence of women in MS. ${ }^{9,14,19,24.29}$

The participants with MS were much older when compared to those without MS, which was found in other studies as well ${ }^{1,9,11,29}$. The importance of age, as a risk factor for MS and CAD, which was shown in the previous studies ${ }^{3}$, should be taken into consideration when interpreting the results. ${ }^{24}$

Our participants with MS had a significantly higher incidence of heart rate abnormalities, myocardial re-infarction, a lower ejection fraction (EF) of the left ventricle and heart failure (HF) when compared to patients from the control group, without MS. This inevitably indicates the more severe form of CAD in the group with MS.

The EF in our group with MS was lower when compared to findings in other studies $47.3 \%{ }^{1}, 49.7 \%{ }^{9}, 50.0 \%^{2}$, $50.6 \%{ }^{14}$, and it indicates the larger damage of the myocardium. It's in correlation with the higher incidence of HF in our patients. The same was noticed in some other studies, as well. ${ }^{2}$

These findings show the resulting negative influence of MS components, insulin resistance, diabetes, and lipid abnormalities on the incidence, severity, and evolution of HF in our participants. It outweighed the positive influence of other MS 
od $57,4 \%{ }^{2}, 70,0 \%{ }^{27}$ i $70,1 \%{ }^{9}$, što predstavlja manju učestalost od naših nalaza.

U nekim studijama ${ }^{21}$ je, međutim, pokazano da je učestalost višesudovne bolesti, u osoba sa MS i koronarnom bolešću, uporediva sa našim nalazima, sa podjednakom učestalošću $91,3 \%$ vs $92,0 \%$.

Druga istraživanja takođe nalaze statistički značajno veću učestalost trosudovne i višesudovne bolesti kod pacijenata sa MS i koronarnom bolešću, u poređenju sa onima bez MS $^{1,3,4,13,23}$, dok su pojedina ${ }^{10,6}$ pokazala veću učestalost trosudovne i višesudovne bolesti, ali bez statističke značajnosti.

Rezultati nekih istraživanja nisu pokazali postojanje značajnih razlika u težini koronarne bolesti između ispitanika sa/bez $\mathrm{MS}^{31}$. U drugim istraživanjima kod ispitanika sa MS zapažen je inverzan odnos sa manjom učestalošću trosudovne bolesti u poređenju sa onima bez $\mathrm{MS}^{24}$. Međutim, druge studije i pored nepostojanja značajnih razlika u broju stenoziranih sudova, između ispitanika sa/bez MS, nalaze značajno veće vrednosti Gensini skora u onih sa MS, čime je kod njih potvrđena teža koronarna bolest ${ }^{10}$.

Iako su po godinama starosti bili uporedivi sa našim ispitanicima, u drugim studijama zapažamo značajno manju učestalost trosudovne i višesudovne bolesti kod bolesnika sa MS, u odnosu na naše nalaze, što se može objasniti razlikama ispitivanih populacija u kliničkim oblicima koronarne bolesti, biohemijskim nalazima i učestalostima tradicionalnih faktora rizika koronarne bolesti. Nađena je veća učestalost dijabetesa, hipertenzije, nivoa ukupnog i LDL-holesterola kod naših ispitanika, u poređenju sa nalazima drugih studija ${ }^{1,2,4,9,24}$. Razlikama doprinose, u nekim slučajevima, etnička pripadnost ispitivanih populacija, životni stil, kulturološke i geografske razlike, genetsko i životno okruženje a značajnu ulogu imaju razlike u starosti i polu ${ }^{16,24,32,33}$.

Redosled učestalosti stenoza pojedinačnih koronarnih arterija u obe grupe je isti, sa najčešćom lezijom LAD, zatim RCA i LCX i statistički značajno većom učestalošću stenoza za sve tri koronarne artrije kod lica sa MS, u odnosu na ona bez MS. Ispitanici sa MS imali su devet puta veću učestalost lezije glavnog stabla (LM) u odnosu na ispitanike bez MS, što nije nađeno u drugim studijama ${ }^{13}$.

Neka istraživanja su pokazala da postoji visoka učestalost MS u bolesnika sa značajnim stenozama LAD $(66,7 \%)$, LCX $(63,2 \%)$ i RCA $(67,6 \%)$, bez značajnih razlika između njih, koja je uporediva sa našim nalazima ${ }^{6}$.

Značajna stenoza LM je, u većini studija, češće zastupljena kod ispitanika sa MS u poređenju sa onima bez MS $(13,1 \% \text { vs } 4,45 \%)^{1}$, što je saglasno našim nalazima. U drugim studijama zapažena je podjednaka $(7,4 \%$ vs $7,3 \%) 13$ ili veća učestalost stenoza LM kod ispitanika bez MS $(4,4 \%)$ u odnosu na one sa MS $(0 \%)^{6}$.

U većini studija pokazana je manja učestalost stenoza pojedinačnih koronarnih arterija kod bolesnika sa koronarnom bolešću i MS u odnosu na naše nalaze, ali je učestalost components on HF - overweight (obesity paradox) and high blood pressure. ${ }^{30}$

The connection between MS and the severity of CAD was shown in other studies, as well. ${ }^{1.327}$ They found the incidence of multi-vessel disease was significantly higher in patients with MS and MI when compared with those with MI but without MS, and it ranged from $57.4 \%{ }^{2}, 70.0 \%{ }^{27}$ to $70.1 \%{ }^{9}$, which is lower incidence than in our findings.

In some studies ${ }^{21}$, however, the incidence of multi-vessel disease, in patients with MS and CAD, was comparable to our findings $91.3 \%$ vs $92.0 \%$.

Other studies also found a statistically significantly higher incidence of triple and multi-vessel disease, in patients with MS and CAD when compared with those without $\mathrm{MS}^{1,3,4,13,23}$, while the others ${ }^{10,6}$ showed a higher incidence of triple and multi-vessel disease, but without statistical significance.

The results of some studies failed to show significant differences in the severity of CAD, in patients with/without MS. ${ }^{31}$ In other studies, in patients with MS, the inverse relation, with a lower incidence of triple-vessel disease, was noticed in comparison with those without MS. ${ }^{24}$ However, other studies besides no significant differences in the number of stenosed arteries, between patients with/without MS, found significantly higher Gensini score, in those with MS. It confirms the more severe form of CAD in these patients. ${ }^{10}$

Although comparable in age with our participants, the participants from other studies had a significantly lower incidence of triple and multi-vessel disease, in patients with MS, then we had. This may be explained by the differences in the examined populations and clinical forms of $\mathrm{CAD}$, lab results, and the incidence of the traditional risk factors for CAD. There was a higher incidence of diabetes, hypertension, total, and LDL-cholesterol in our participants when compared to the findings from other studies. ${ }^{1,2,4,9,24}$ In some cases, the differences are contributed to ethnicity, lifestyle, cultural and geographic differences, genetics, environment. The age and gender differences are important, as well. ${ }^{16,24,32,33}$

The incidence of the stenosis of the singular coronary arteries is the same in both groups. The most frequent stenosis is in LAD, followed by RCA and LCx. Statistically significantly higher incidence of the stenosis for all three coronary arteries was found in patients with MS when compared to those without MS. The participants with MS had a nine times higher incidence of the left main lesion (LM) in comparison with those without MS. This wasn 't found in other studies. ${ }^{13}$

Some studies showed there was a high incidence of MS in patients with significant stenosis of LAD (66.7\%), LCx (63.2\%) and RCA (67.6\%), with no remarkable differences between them, and they are comparable to our results. ${ }^{6}$

Significant stenosis of LM, in most studies, is more common in patients with MS when compared to those without it (13.1\% vs 4.45\%). ${ }^{1}$ This was in correlation with our re- 
stenoza LAD u svim studijama najveća, kao i u grupi naših ispitanika ${ }^{13,34}$.

U nekim istraživanjima pokazano je, suprotno našim nalazima, da je učestalost značajnih stenoza glavnih koronarnih arterija, mada statistički neznatna, manja kod pacijenata sa MS u odnosu na one bez MS: LAD 21,9\% vs 23,8\%, LCX $5,5 \%$ vs $6,9 \%$ i RCA $11,4 \%$ vs $11,9 \%$, sa izrazito niskom učestalošću lezija u obe grupe, u poređenju sa našim ispitanici$\mathrm{ma}^{6}$.

Većina studija pokazuje značajnu povezanost MS sa većom učestalošću CABG i PCI ${ }^{1,21}$ kod pacijenata sa MS, što je potvrđeno i ovim istraživanjem.

Naši bolesnici sa MS bili su znatno češće podvrgnuti CABG i znatno manje PCI, u poređenju sa bolesnicima bez MS, što je zapaženo i u drugim studijama ${ }^{1,23}$, u korelaciji je sa težinom njihovog koronarografskog nalaza i potvrda su njihove teže koronarne bolesti.

Studija Reza Mira ${ }^{23}$ koja je uporediva sa našom po težini koronarne bolesti ispitanika, takođe je pokazala veću podvrgnutost CABG bolesnika sa MS, u odnosu na one bez MS (46,4\% vs 40,3\%) i manju primenu PCI (51,2\% vs 53,7\%), što je statistički neznatno, ali sa većom učestalošću PCI u odnosu na naše nalaze. Medikamentnom terapijom lečen je veći broj naših bolesnika sa MS, ali bez statističke značajnosti u odnosu na bolesnike bez MS, sa učestalošću koja je pet puta veća od nalaza drugih studija ${ }^{23}$, koje su pokazale manju zastupljenost medikamentne terapije u bolesnika sa MS $(2,4 \%)$, u poređenju sa našim nalazima i češću, statistički neznatnu primenu ovakvog lečenja u bolesnika bez MS $(6,0 \%)^{23}$.

\section{Zaključak}

Osobe sa metaboličkim sindromom imaju teže angiografske promene na koronarnim arterijama sa značajno većom učestalošću trosudovne i višesudovne bolesti, lezija pojedinačnih koronarnih arterija LAD, LCx, RCA, većom učestalošću njihovih proksimalnih stenoza i ukupnog broja značajnih stenoza svih koronarnih arterija, u poređenju sa osobama bez MS, što pokazuje da je metabolički sindrom značajan faktor rizika za nastanak i razvoj teže koronarne bolesti. sults, but in some other studies, there was no difference (7.4\% vs $7.3 \%)^{13}$, or the incidence of LM stenosis was even higher in patients without MS $(4,4 \%)$ when compared to those with MS $(0 \%)^{6}$.

The lower incidence of the singular stenosis of the coronary arteries, in patients with MS and CAD, was found in the majority of the studies but not in our study. The incidence of LAD stenosis was the highest in all studies, including ours. ${ }^{13.14}$

Some studies showed, contrary to our findings, the incidence of significant stenoses of the main coronary arteries, although statistically small, was lower in patients with MS when compared to those without it: LAD $21.9 \%$ vs $23.8 \%$, LCx $5.5 \%$ vs $6.9 \%$ and RCA $11.4 \%$ vs $11.9 \%$. There was a distinctly lower incidence of lesions in both groups when compared to our findings. ${ }^{6}$

The majority of the studies showed a distinct correlation between MS and higher incidence of $\mathrm{CABG}$ and $\mathrm{PCI}^{1,21}$, in patients with MS, which was the case in our study, as well.

Our patients with MS were more likely to undergo CABG, and less likely to have PCI when compared to patients without MS. These were the findings in other studies, as well ${ }^{1.23}$, and they correlated with the severity of the angiographic findings and confirmed a more severe form of the disease.

The study of R. Miri ${ }^{23}$, which was comparable to ours, as far as the severity of the CAD was concerned, also showed a higher incidence of CABG in patients with MS when compared to those without it ( $46.4 \%$ vs $40.3 \%$ ), and lower incidence of PCI (51.2\% vs 53.7\%). The findings were statistically insignificant and had a higher incidence of PCI than in our study. The majority of our patients with MS had drug treatment and there was no significant difference in comparisson to those without MS. But our incidence was five times higher than in other studies ${ }^{23}$, which found a lower incidence of drug therapy in patients with MS (2.4\%) when compared to our findings, and more frequent, although statistically insignificant, use in patients without MS $(6.0 \%){ }^{23}$

\section{Conclusion}

Participants with metabolic syndrome had more severe angiography findings in their coronary arteries. They had a significantly higher incidence of triple and multi-vessel disease, lesions of the singular coronary arteries LAD, LCx, RCA, a higher incidence of proximal stenoses, and a total number of the significant stenoses of coronary arteries when compared to the patients without MS. This clearly shows MS is an important risk factor for CAD. 


\section{Literatura / Reference}

1. Kumar SS, Goel A, Madaan A, Thakur R, Krishna V, Singh K et al. Prevalence of Metabolic Syndrome and its Clinical and Angiographic Profile in Patients With Naive Acute Coronary Syndrome in North Indian Population. J Clin Med Res 2016 Sep;8(9):667-673.

2. Mornar Jelavić M. Utjecaj antropometrijskih parametara $i$ metaboličkoga sindroma na težinu $i$ prognozu akutnoga infarkta miokarda sa ST-elevacijom. Doktorski rad, Sveučilište u Zagrebu, Stomatološki fakultet, Zagreb 2015.

3. Abrar A, Khan S, Rehman A, Jan T. Angiographic severity of coronary artery disease in patients with metabolic syndrome. Gomal J Med Sci 2011 JulyDecember;9(2):194-197.

4. Mahalle N, Garg MK, Naik SS, Kulkarni MV. Angiographic severity of coronary artery disease. Indian J Endocrinol Metab 2014 Sep;18(15):708-714.

5. Uppalakal B, Sankar Karanayil L. Incidence of Metabolic Syndrome in Patients Admitted to Medical Wards with ST Elevation Myocardial Infarction. J Clin Diagn Res 2017 Mar;11(3):17-20.

6. Mahmood AM, Ahmed MH, Mohammad JB. Prevalence of metabolic syndrome in angiographically confirmed coronary artery disease. Med J Babylon 2018 Dec;15:310-315.

7. Stojanović S. Povezanost nivoa adiponektina u serumu pacijenta $u$ zavisnosti od metaboličkog sindroma $i$ koronarne bolesti. Doktorska disertacija, Univerzitet u Kragujevcu, Fakultet medicinskih nauka, Kragujevac, Srbija 2014.

8. Nolan P, Carrick-Ranson G, Stinear J, Reading S, Dalleck L. Prevalence of metabolic syndrome and metabolic syndrome components in young adults. A pooled analysis. Prev Med Rep 2017 Sep; 7:211-215.

9. Lović M, Đorđević D, Tasić I, Nedeljković I. Impact of metabolic syndrome on clinical severity and long-term prognosis in patients with myocardial infarction with ST-segment elevation. Hellenic Journal of Cardiology 2018 JulyAugust;59(4):226-231.

10. Jong-Youn K, Hee-Sun M, Byoung Kwon L, Seong Bo Y, Eui-Young Ch, Pil-Ki $\mathrm{M}$ et al. Impact of Metabolic Syndrome and Its Individual Components on the Presence and Severity of Angiographic Coronary Artery Disease. Yonsei Med J 2010;51(59):676-682.
11. Pandey S, Baral N, Majhi S, Acharya P, Karki P, Shrestha S, et al. Prevalence of the metabolic syndrome in acute myocardial infarction and its impact on hospital outcomes. Int J Diabetes Dev Ctries 2009 Apr-Jun;29(2):52-55.

12. Khan R, Buse J, Ferrannini E, Stern M. The Metabolic Syndrome: Time for a Critical Appraisal. Diabetes Care 2005 Sep;28(9):2289-2304.

13. Hassanin N, Gharib S, El Ramly MZ, Meged MA, Makram A. Metabolic syndrome and coronary artery disease in young Egyptians presenting with acute coronary syndrome. Kasr Al Ainy Med J 2015 Apr;21:27-33.

14. Abdellatif AM, Solovyova AV, Rakita DR, Shishova TA, Shuvalova YA, Kaminnyy AI. Effect of metabolic syndrome on left ventricular wall motion in patients with ST segment elevation myocardial infarction. Fundamental-research 2014;10(4):615619. Available from ; https://www. fundamental; research.ru/ru/article/ view?id $=35589$

15. Stoičkov V, Deljanin Ilić M. Modifikacija faktora rizika u prevenciji kardiovaskularnih bolesti. Aktuelnosti u kardiologiji. Balneoclimatologia 2007 Maj;31(1):3-27.

16. Gami AS, Witt BJ, Howard DE, Erwin PJ, Gami LA, Somers VK, Montori VM. Metabolic syndrome and risk of incident cardiovascular events and death a systematic review and meta-analysis of longitudinal studies. J Am Coll Cardiol $2007 \mathrm{Jan} ; 49(4): 403-414$.

17. Pećanac Ž, Stanetić K, Šormaz Lj. Učestalost komponenti metaboličkog sindroma kod bolesnika sa ishemijskom bolesti srca. Biomedicinska istraživanja 2018; 9(1):16-25.

18. Stojisavljević D. Prevalencija metaboličkog sindroma kod odraslih stanovnika Republike Srpske. Doktorska disertacija, Univerzitet u Beogradu, Medicinski fakultet, Beograd 2014.

19. Montazerifar F, Bolouri A, Mahmoudi Mozaffar M, Karajibani M. The Prevalence of Metabolic Syndrome in Coronary Artery Disease Patients. Cardio Res 2016 Dec;97(6):202-208.

20. Mc Neill AM, Rosamond WD, Girman CJ, Golde SH, Schmidt MI, East HE et al. The Metabolic Syndrome and 11-year Risk of Incident Cardiovascular Disease in the Atherosclerosis Risk in Communities Study. Diabetes Care 2005 Feb; 28(2): 385-390.
21. Malik S, Wong ND, Franklin SS, Kamath T, L Italien G, Pio J, Williams GR. Impact of the Metabolic Syndrome on Mortality from Coronary Heart Disease, Cardiovascular Disease and all Causes in United States Adults. Circulation 2004 Sep;110(10):1245-1250.

22. Hunt K, Resendez RG, Williams K, Haffner SM, Stern MP. National Choletsreol Education Program versus World Health Organization Metabolic Syndrome in Relation to AllCause and Cardiovascular Mortality in the San Antonio Heart Study. Circulation 2004 Sep;110(10):1251-1257.

23. Miri R, Sajjadieh A, Parsamahjoob M, Hajibaratali B, Shekarchiyadeh M, Asghar Kolahi A, et al. Relationship between metabolic syndrome and angiographic severity of coronary artery disease. ARYA Atheroscler 2016 Sep; 12(5):220-225.

24. Khan A, Saif M, Nargis S, Nagvi F, Samad AM, Rashed Z, Ishaq M. Prevalence and predictors of metabolic syndrome in patients with coronary artery disease. Pak Heart J 2018;51(4):280-285.

25. Resnick HE, Jones K, Ruotolo G, Jain AK, Henderson J, Lu W, Howard BW. Strong Heart Study: Insulin Resistence, the Metabolic Syndrome and Risk of Incident Cardiovascular Disease in Nondiabetic American Indians. Diabetes Care 2003 Mar; 26(3):861-867.

26. Afsana F, Latif Z, Khan S, Talukder S. Metabolic syndrome and cardiovascular risk in diabetic subject. CVD Prevention and Control 2010 June;5:59-62.

27. Stanković I, Tesić V, Kovačević V, Dedović V, Živković M, Aleksandrić C, et al. Prevalencija i prognostički značaj metaboličkog sindroma kod pacijenata sa akutnim infarktom miokarda sa ST elevacijom. Aktuelnosti u kardiologiji 3, Balneoklimatologia, 2011 maj;35(2): 67-75.

28. Bonamichi BD, Parente EB, Campos AC, Cury AN, Salles JE. Hyperglycemia effect on coronary disease in patients with metabolic syndrome evaluated by intracoronary ultrasonography. PloS One 2017 Feb; 12(2):e0171733 doi:10.1371/ journal.pone. 0171733 .

29. Zeller M, Steg PG, Ravisy J, Laurent Y, Janin-Manificat LL Huillier I, et al. Prevalence and impact of metabolic syndrome on hospital outcomes in acute myocardial infarction. Arch Intern Med 2005; 165:1192-1198. 
30. Perrone-Filardi P, Paolillo S, Costanzo P, Savarese G, Trimarco B, Bonow R. The role of metabolic syndrome in heart failure. Europian Heart Journal 2015 Aug;36:2630-2634.

31. Widecka K, Safranow K, Lewandowski M, Przybycien K, Goracy J, KornacewiczJach Z. Angiographic severity of coronary artery disease and cardiovascular risk in acute coronary syndrome in patients with metabolic syndrome. Kardiol Pol 2018 Januar;76(3):662-668.
32. Ramić E, Prasko S, Batić Mujanović O, Gavran L. Metabolic syndrome-theory and practice. Mater Sociomed 2016 Feb;28(1):71-73.

33. Saklayen M. The Global Epidemic of the Metabolic Syndrome. Curr Hypertens Rep 2018 Feb;20(2):12 doi: 10.1007/s11906018-0812-z.

34. Oz TK, Özbilgin N, Sungur A, Bas EG, Zengin A, Gürol T, et al. Prevalence of metabolic syndrome in young patients with ST-elevation myocardial infarction. Int J Cardiovascular.Acad, 2018 Jul;4(3):53-58.
Autori izjavljuju da nemaju sukob interesa Conflict of interest: None declared

Primljen - Received

Ispravljen - Corrected

Prihvaćen - Accepted 01.07.2020. 